\title{
Development and evaluation of equations in the Cornell Net Carbohydrate and Protein System to predict nitrogen excretion in lactating dairy cows
}

\author{
R. J. Higgs, L. E. Chase, and M. E. Van Amburgh ${ }^{1}$ \\ Department of Animal Science, Cornell University, Ithaca, NY 14853
}

\begin{abstract}
Nitrogen excretion is of particular concern on dairy farms, not only because of its effects on water quality, but also because of the subsequent release of gases such as ammonia to the atmosphere. To manage $\mathrm{N}$ excretion, accurate estimates of urinary $\mathrm{N}(\mathrm{UN})$ and fecal $\mathrm{N}$ (FN) are needed. On commercial farms, directly measuring UN and FN is impractical, meaning that quantification must be based on predictions rather than measured data. The purpose of this study was to use a statistical approach to develop equations and evaluate the Cornell Net Carbohydrate and Protein System's (CNCPS) ability to predict $\mathrm{N}$ excretion in lactating dairy cows, and to compare CNCPS predictions to other equations in the literature. Urinary $\mathrm{N}$ was overpredicted by the CNCPS due to inconsistencies in $\mathrm{N}$ accounting within the model that partitioned more $\mathrm{N}$ to feces than urine, although predicted total $\mathrm{N}$ excretion was reasonable. Data to refine model predictions were compiled from published studies $(\mathrm{n}=32)$ that reported total collection $\mathrm{N}$ balance results. Considerable care was taken to ensure the data included in the development data set $(\mathrm{n}=104)$ accounted for $>90 \%$ of the $\mathrm{N}$ intake (NI). Unaccounted $\mathrm{N}$ for the compiled data set was $1.47 \pm 4.60 \%$ (mean $\pm \mathrm{SD}$ ). The results showed that FN predictions could be improved by using a modification of a previously published equation: $\mathrm{FN}$ $(\mathrm{g} / \mathrm{d})=[\{[\mathrm{NI}(\mathrm{g} / \mathrm{kg}$ of organic matter $) \times(1-0.842)]+$ $4.3\} \times$ organic matter intake $(\mathrm{kg} / \mathrm{d})] \times 1.20$, which, when evaluated against the compiled $\mathrm{N}$ balance data, had a squared coefficient of determination based on a mean study effect $\left(\mathrm{R}_{\mathrm{MP}}^{2}\right)$ of 0.73 , concurrent correlation coefficient (CCC) of 0.83 and a root mean square error (RMSE) of $10.38 \mathrm{~g} / \mathrm{d}$. Urinary $\mathrm{N}$ is calculated in the CNCPS as the difference between NI and other N excretion and losses. Incorporating the more accurate FN prediction into the current CNCPS framework and correcting an internal calculation error considerably improved UN predictions $\left(\mathrm{RMSE}=12.73 \mathrm{~g} / \mathrm{d}, \mathrm{R}_{\mathrm{MP}}^{2}=\right.$
\end{abstract}

Received August 8, 2011.

Accepted November 20, 2011.

${ }^{1}$ Corresponding author: mev1@cornell.edu
0.86 , CCC $=0.90)$. The changes to FN and UN translated into an improved prediction of total manure $\mathrm{N}$ excretion $\left(\mathrm{RMSE}=12.42 \mathrm{~g} / \mathrm{d}, \mathrm{R}_{\mathrm{MP}}^{2}=0.96, \mathrm{CCC}=\right.$ 0.97 ) and allows nutritionists and farm advisors to evaluate these factors during the ration formulation process.

Key words: nitrogen excretion, dairy cow, modeling

\section{INTRODUCTION}

Dairy producers in the United States are currently under pressure to use production systems that are more cost efficient and have a smaller environmental footprint. Central to this debate is the management of nutrients, such as $\mathrm{N}$ and $\mathrm{P}$, due to their key roles in ground- and surface-water pollution (Dou et al., 1998). Nitrogen is of particular concern on farms, not only because of its effects on water quality, but also because of the subsequent release of gases such as ammonia and nitrous oxide to the atmosphere (NRC, 2003). To date, no direct cost has been associated with the amount of $\mathrm{N}$ excreted by farms in North America. However, certain European countries (Belgium, Denmark, France, and the Netherlands) tax farmers based on the amount of $\mathrm{N}$ excreted on the farm (OECD, 2004). This type of regulation could occur in the United States and could shift the nutritional formulation and management goals on many farms (NRC, 2003).

To comply with future environmental standards, robust methods that quantify $\mathrm{N}$ outputs from dairy farms will be required (NRC, 2003). Directly measuring urinary $\mathrm{N}(\mathbf{U N})$ and fecal $\mathrm{N}(\mathbf{F N})$ on commercial farms is impractical, meaning that quantification must be based on predicted rather than measured data. Equations are available that predict manure $\mathrm{N}$ excretion based on diet characteristics, milk yield, and MUN (Nennich et al., 2005; Nennich et al., 2006). These equations are useful and are approved for use in estimating manure $\mathrm{N}$ excretion in establishing manure management plans.

To be more practical, it would be appropriate to have equations that were integrated into ration evaluation and balancing software so that the nutritionist could be made aware of the excretion predictions of particular diets under farm-specific conditions. The Cornell 
Net Carbohydrate and Protein System (CNCPS) is a mathematical model designed to evaluate the nutrient requirements of cattle over a wide range of environmental, dietary, management, and production situations (Fox et al., 2004; Tylutki et al., 2008). The CNCPS also includes estimates of $\mathrm{N}$ and $\mathrm{P}$ excretion, enabling integration with whole-farm nutrient management plans (Fox et al., 2004; Tylutki et al., 2008). An important constraint imposed during the development of the CNCPS was that the inputs used must be routinely available on most farms so the CNCPS has broad relevance for both research purposes and commercial farms. Currently, the model predicts total manure N (MN) adequately but the ratio of UN to $\mathrm{FN}$ is underpredicted (Fox et al., 2004). For the CNCPS to be used effectively in nutrient management plans, more accurate estimates of UN and FN are required. The purpose of this study was to evaluate the current CNCPS predictions for UN and FN excretion and compare these to other relevant equations from the literature and developed updated equations to be used in the model.

\section{MATERIALS AND METHODS}

\section{Data Set Development}

Data for this evaluation were compiled from published studies that completed total collection $\mathrm{N}$ balance trials on lactating dairy cows. Observed study data for $\mathrm{N}$ intake (NI), milk N, FN, and UN were compared with CNCPS predictions using version CNCPS 6.1. Studies were selected that presented the dietary and animal information required to run a simulation in the CNCPS. This included a description of housing conditions, milk yield, milk fat, milk protein, BW, stage of lactation, and stage of pregnancy. If stage of pregnancy and stage of lactation were not given, CNCPS default values were used. Required dietary information included DMI and a description and chemical analysis of the ration fed for each treatment. Studies often provided chemical analyses for forages and the complete ration, but not for the concentrates. If concentrate composition was not given ( $72 \%$ of studies), ingredients were selected from the CNCPS feed library, and used without alteration. If an ingredient was not present in the CNCPS feed library, its composition was obtained from the NRC (2001). Some studies presented a chemical analysis of the complete ration, but not the forages ( $28 \%$ of studies); in this case, forage $\mathrm{CP}$ and NDF concentrations were back calculated from the complete ration composition presented by the study, and concentrate compositions from the CNCPS feed library. The calculated CP and NDF concentrations were then compared with corresponding forages in the CNCPS feed library and the closest match was selected. Minor adjustments were subsequently made to $\mathrm{CP}$ and NDF to get an exact match. When making adjustments, consideration was given to the level of variation expected from different types of feeds and the proportion of each feed in the ration. For example, forages generally made up $>50 \%$ of the ration and were generally less homogenous than concentrate ingredients. Therefore, small adjustments to forage composition within the expected range of variation were more effective and considered more realistic than large changes to specific concentrate ingredients. For example, in the study of Weiss and Wyatt (2006) information was presented on the chemical composition of forages and total diet, but not concentrates. Using feed library values for the concentrates, and the values provided for the forages, CP in the DP (dual-purpose) silage, high CP treatment was calculated to be $16.9 \%$ DM. However, the study reports $17.1 \%$ CP. To reconcile the calculated and reported values, corn silage in the ration was shifted from $8.06 \% \mathrm{CP}$ to $8.36 \% \mathrm{CP}$. To achieve the same change using corn grain, which was the next largest dietary component, $\mathrm{CP}$ would have had to be changed from 9\% DM to $10 \% \mathrm{DM}$. We deemed it more likely that the corn silage was $8.36 \% \mathrm{CP}$ than the corn grain $10 \% \mathrm{CP}$.

Our objective was to evaluate the CNCPS and alternative models for their ability to partition MN into FN and UN. To avoid confounding the prediction of FN and UN, it was important that NI and milk N reported by the study were consistent with that accounted for by the model. Conflicting data on milk yield and milk protein composition compared with milk $\mathrm{N}$ output were presented in some studies. Nitrogen balance trials were often run in conjunction with larger production trials. Cows might have decreased milk yield when housed in metabolism stalls for the $\mathrm{N}$ balance component of the study compared with freestall or tie-stall housing in the production trial. Therefore, when milk yield for the $\mathrm{N}$ balance period was not presented, milk yield was adjusted to ensure milk $\mathrm{N}$ output reported by the study was the same as that accounted for by the model. For example, in the study of Haig et al. (2002), milk yield and milk CP was reported as $25.3 \mathrm{~kg} / \mathrm{d}$ and $3.3 \%$, respectively, for the low treatment. Using these data, milk $\mathrm{N}$ is calculated to be $131 \mathrm{~g} / \mathrm{d}$; however, the study reports $120 \mathrm{~g} / \mathrm{d}$. Back calculating milk yield from milk $\mathrm{N}$ using 6.38 as the correction factor yields $23.2 \mathrm{~kg} / \mathrm{d}$. To ensure the amount of intake $\mathrm{N}$ partitioned to milk in the model was consistent with that reported by the study, the back calculated milk yield was used.

Nitrogen that could not be accounted for in the milk, feces, or urine was generally reported by the study as retained $\mathrm{N}$. Retained $\mathrm{N}$ was sometimes unrealistically high, suggesting losses during the collection or analysis 
Table 1. Studies included in the data set used to evaluate model predictions

Studies included in the data set

Beckman and Weiss (2005)

Birkelo et al. (2004)

Brito et al. (2008)

Castillo et al. (2001)

Cherney et al. (2003)

Dinn et al. (1998)

Drackley and Elliott (1993)

Elliott et al. (1993)

Erdman et al. (1982)

Flis and Wattiaux (2005)

Grieve et al. (1973)

Gruber et al. (1999)

Haig et al. (2002)

Holden et al. (1994)

Hristov et al. (2004)

Jacobson et al. (1969)

Jonker et al. (2002)

Knowlton et al. (2001)

Martineau et al. (2007)

Moorby et al. (2009)

Noftsger and St-Pierre (2003)

Petit and Tremblay (1995)

Raggio et al. (2004)

Ruiz et al. (2001)

Ruiz et al. (2002)

Schauff et al. (1992)

van Dorland et al. (2007)

Wattiaux and Karg (2004)

Weiss and Wyatt (2006)

Wilkerson et al. (1997)

Wohlt et al. (1991)

Wright et al. (2005)

of feces and urine, or both (Spanghero and Kowalski, 1997; Reynolds and Kristensen, 2008). Studies were omitted from the initial data set if retained or unaccounted $\mathrm{N}$ was above $10 \%$ in all of the treatments. Individual treatments were subsequently removed if unaccounted $\mathrm{N}$ was greater than $1 \mathrm{SD}(5.9 \%)$ from the mean unaccounted $\mathrm{N}$ of the compiled data set. Adjustments were made to fecal $\mathrm{N}$ if samples were dried before analysis as per Juko et al. (1961). Consideration was also given to the laboratory method used to measure milk protein and scurf losses (Spanghero and Kowalski, 1997). Milk protein concentrations reported on a true protein basis were converted to a $\mathrm{CP}$ basis and multiplied by a factor of 6.38 to give milk $\mathrm{N}$, whereas scurf losses were estimated as per Fox et al. (2004). Urinary $\mathrm{N}$ losses were considered minor given that all the studies acidified urine during collection (Spanghero and Kowalski, 1997). The resulting data set comprised 32 studies (Table 1) and 104 treatments. Unaccounted $\mathrm{N}$ for the entire data set was $1.5 \% \pm 4.6 \%$ (mean \pm $\mathrm{SD})$. The range in dietary and animal characteristics is summarized in Table 2. A wide variety of forages were fed among treatments, and included corn silage (23\%), alfalfa silage $(12 \%)$, grass silage $(27 \%)$, corn silage-

alfalfa silage $\operatorname{mix}(27 \%)$, corn silage-grass silage mix (5\%), and other $(7 \%)$. Other included fresh pasture, cereal silages, and fresh red clover. The concentrate mixes and ingredients represented were also diverse.

\section{Statistical Analysis}

A mixed model using the restricted maximum likelihood (REML) procedure of SAS Institute (2007) was used to analyze the data using the model

$$
Y_{i j}=\left(\beta_{0}+b_{0 i}\right)+\left(\beta_{1}+b_{1 i}\right) X_{i j}+\varepsilon_{i j},
$$

where $Y_{i j}=$ the expected outcome for the dependent variable $Y$ observed at repetition $j$ of the continuous variable $X$ in study $i, \beta_{0}=$ the overall intercept across all studies, $b_{0 i}=$ the random effect of study $i, \beta_{1}=$ the overall slope of $Y$ on $X$ across all studies, $b_{1 i}=$ the random effect of study $i$ on the slope of $Y$ on $\mathrm{X}, X_{i j}=$ the data associated with repetition $j$ of the continuous variable $X$ in study $i$, and $\varepsilon_{i j}=$ random variation.

The variance components in the model adhered to the following assumptions: $b_{0 i} \sim \mathrm{N}\left(0, \sigma_{0}^{2}\right), b_{1 i} \sim \mathrm{N}\left(0, \sigma_{1}^{2}\right)$, and $\varepsilon_{i j} \sim \mathrm{N}\left(0, \sigma_{\varepsilon}^{2}\right)$. Further information on mixed model methodology can be found in a review by St-Pierre (2001).

The current CNCPS equations for predicting FN and UN were compared with other equations presented in the literature (Nennich et al., 2006; Huhtanen et al., 2008; Marini et al., 2008). The model fit for the current data set was also calculated and evaluated. Descriptions of the equations evaluated and abbreviations used are presented in Tables 3 and 4, respectively. During analysis, model predicted values were plotted on the $\mathrm{x}$-axis, whereas the observed values were plotted on the $\mathrm{y}$-axis. This is because the model-predicted values are deterministic and contain no random variation, whereas the observed values contain natural variability (Tedeschi, 2006). Consequently, a $\beta_{1}$ that is greater than 1 represents an overprediction, whereas a $\beta_{1}$ that is less than 1 represents an underprediction. To allow for the

Table 2. Descriptive statistics for dietary and animal characteristics from the compiled data set used to evaluate model predictions (32 studies, 104 treatments)

\begin{tabular}{lcccc}
\hline Item & Mean & SD & Minimum & Maximum \\
\hline Dietary characteristic & & & & \\
DMI (kg/cow per day) & 20.3 & 3.7 & 8.9 & 27.2 \\
CP (\% DM) & 16.9 & 2.5 & 9.4 & 22.8 \\
NDF (\% DM) & 32.5 & 5.9 & 16.7 & 43.2 \\
Animal characteristic & & & & \\
Full BW (kg) & 611.1 & 58.6 & 456.0 & 768.0 \\
Milk yield (kg/d) & 29.9 & 8.5 & 9.6 & 4.9 \\
Milk fat (\%) & 3.6 & 0.4 & 2.5 & 3.4 \\
Milk true protein (\%) & 2.9 & 0.2 & 2.3 & \\
\hline
\end{tabular}


Table 3. Definitions and units associated with variables used in prediction equations

\begin{tabular}{lll}
\hline Variable & Definition & Units \\
\hline DMI & DMI & $\mathrm{kg} / \mathrm{d}$ \\
FEPB3 & Amount of feed B3 protein fraction in feces & $\mathrm{g} / \mathrm{d}$ \\
FEPC & Amount of feed protein fraction C in feces & $\mathrm{g} / \mathrm{d}$ \\
FEBCP & Amount of fecal bacterial protein & $\mathrm{g} / \mathrm{d}$ \\
IDM & Indigestible DMI & $\mathrm{g} / \mathrm{d}$ \\
Milk & Milk production & $\mathrm{kg} / \mathrm{d}$ \\
Milk CP & CP content of milk & $\%$ \\
MP $_{\mathrm{g}}$ & MP requirement for gain & $\mathrm{g} / \mathrm{d}$ \\
MP $_{\text {Preg }}$ & MP requirement for pregnancy & $\mathrm{g} / \mathrm{d}$ \\
NI & Nitrogen intake & $\mathrm{g} / \mathrm{d}$ \\
OM & OM & $\mathrm{g} / \mathrm{kg}$ \\
OMI & OM intake & $\mathrm{kg} / \mathrm{d}$ \\
RDP & RDP & $\mathrm{g} / \mathrm{d}$ \\
SPA & Requirement of net protein for scurf losses & $\mathrm{g} / \mathrm{d}$ \\
\hline
\end{tabular}

direct comparison of $\beta_{1}$ across different models, $\beta_{0}$ was forced through the origin. Theoretically, this should have occurred naturally, and the range in the data meant that forcing it had little, if any, effect on model outcomes. The squared sample correlation coefficients reported were based on either the BLUP $\left(\mathrm{R}_{\mathrm{BLUP}}^{2}\right)$ or model predictions using a mean study effect $\left(\mathrm{R}_{\mathrm{MP}}^{2}\right)$.

Additional model adequacy statistics were calculated to give further insight into the accuracy, precision, and sources of error in each model (Tedeschi, 2006). Mean square prediction errors (MSPE) were used to indicate accuracy. A decomposition of the MSPE was also performed to give an estimation of the error due to central tendency (mean bias), regression (systematic bias), and random variation. Concordance correlation coefficients (CCC) were used to simultaneously account for accuracy and precision. Concordance correlation coefficients can vary from 0 to 1 , with a value of 1 indicating that no deviation from the $\mathrm{Y}=\mathrm{X}$ line has occurred. Further description of these statistics is provided by Tedeschi (2006).

A subsequent data set consisting of 3 studies (Kauffman and St-Pierre, 2001; Vanhatalo et al., 2009; Weiss et al., 2009) and 22 treatments was also compiled and used to independently evaluate the equations derived from the main data set. Mean unaccounted $\mathrm{N}$ from the validation data set was $6.1 \% \pm 3.6 \%$. Data were analyzed using the model described above.

\section{Fecal Nitrogen}

\section{RESULTS}

Model adequacy statistics for FN and UN predictions are shown in Table 5. Among all 104 treatments, the CNCPS predicted FN accurately with a slope of 1.00

Table 4. Source and description of the equations used to predict fecal N (FN; g/d) and urinary N (UN; g/d)

\begin{tabular}{|c|c|c|}
\hline $\begin{array}{l}\text { Equation } \\
\text { name }\end{array}$ & Source & Equation $^{1}$ \\
\hline $\mathrm{FN} \mathrm{CNCPS}^{2}$ & Fox et al. (2004) & $\mathrm{FN}=[(\mathrm{FEPB} 3+\mathrm{FEPC}+\mathrm{FEBCP}+\mathrm{IDM}) \times 0.09] / 6.25$ \\
\hline FN 1 & Marini et al. (2008) & $\mathrm{FN}=\{[\mathrm{NI}(\mathrm{g} / \mathrm{kg}$ of $\mathrm{OM}) \times(1-0.842)]+4.3\} \times \mathrm{OMI}$ \\
\hline FN proposed ${ }^{3}$ & Adapted from Marini et al. (2008) & $\mathrm{FN}=(\{[\mathrm{NI}(\mathrm{g} / \mathrm{kg}$ of $\mathrm{OM}) \times(1-0.842)]+4.3\} \times \mathrm{OMI}) \times 1.20$ \\
\hline $\mathrm{FN} 4^{3}$ & Adapted from Huhtanen et al. (2008) & $\mathrm{FN}=[-21+(\mathrm{DMI} \times 6.73)+(\mathrm{NI} \times 0.101)] \times 1.17$ \\
\hline $\mathrm{FN} 5^{4}$ & Current data set (Table 1) & $\mathrm{FN}=-21+(\mathrm{DMI} \times 6.25)+(\mathrm{NI} \times 0.17)$ \\
\hline UN 2 & Huhtanen et al. (2008) & $\mathrm{UN}=-91+(\mathrm{milk} \times 11.4)$ \\
\hline UN 3 & Huhtanen et al. (2008) & $\mathrm{UN}=27+(\mathrm{NI} \times 0.844)+(\mathrm{DMI} \times-13)$ \\
\hline UN 4 & Huhtanen et al. (2008) & $\mathrm{UN}=40+(\mathrm{NI} \times 0.879)+(\mathrm{DMI} \times-9)+(\operatorname{milk} \times-3.9)$ \\
\hline UN 5 & Nennich et al. (2006) & $\mathrm{UN}=(\mathrm{RDP} \times 0.0628)+55.6$ \\
\hline
\end{tabular}

${ }^{1}$ FEPB3 = amount of feed B3 protein fraction in feces; FEPC = amount of feed protein fraction C in feces; FEBCP = amount of fecal bacterial protein; IDM = indigestible $\mathrm{DMI} ; \mathrm{NI}=\mathrm{N}$ intake; $\mathrm{OMI}=\mathrm{OM}$ intake; $\mathrm{SPA}=$ requirement of net protein for scurf losses; $\mathrm{MP}$ Preg $=\mathrm{MP}$ requirement for pregnancy; $\mathrm{MP}_{\mathrm{g}}=\mathrm{MP}$ requirement for gain.

${ }^{2}$ CNCPS $=$ Cornell Net Carbohydrate and Protein System.

${ }^{3}$ Original equations from Marini et al. (2008) and Huhtanen et al. (2008) (FN 1 and 2, respectively) were adjusted to calibrate FN predictions to the current data set (32 studies, 104 treatments). The adjustments were based on the $\beta 1$ coefficients derived from the mixed model analysis (Table 5).

${ }^{4} \mathrm{FN} 5=$ the regression equation derived from the current data set using DMI and NI as predictor variables. 
and an MSPE of 884. The random effect of study in the mixed model analysis accounted for greater than $85 \%$ of the variation in predicted FN for every equation tested. Total variation was, therefore, explained with a great deal of precision as indicted by the high $\mathrm{R}_{\text {BLUP }}^{2}$ values. Variation attributed to the difference in slope among study, and the percentage of MSPE accounted for by systematic bias was either absent or minimal in every equation suggesting that, within study, the equations were very consistent. Equations FN 1 and 2, underpredicted $\mathrm{FN}$ by 20 and $17 \%$, respectively, but both were more precise than the FN equation currently used in the CNCPS $\left(\mathrm{R}_{\mathrm{MP}}^{2}=0.73\right.$ and 0.72 , respectively $)$. The high proportion of MSPE attributed to mean bias and the lack of error due to slope among study and systematic bias indicated these equations described the same biological relationship but differed in the total amount of FN predicted. Given this, FN 1 and FN 2 were adjusted to the current data set based on their corresponding $\beta_{1}$ coefficients (Table 5) and re-evaluated (FN proposed and FN 4, respectively). The adjusted equations were both more accurate and more precise than the FN equation used in the CNCPS, as indicated by higher $\mathrm{R}_{\mathrm{MP}}^{2}$ values, lower MSPE, and higher CCC (Table 5). The equation developed from the current data set (FN 5 in Table 4) was comparable to FN proposed and FN 4, but slightly less accurate than FN proposed, as indicated by the higher MSPE (787) and slightly higher proportion of error due to mean bias. Therefore, FN proposed was the strongest predictor of FN (Figure 1). When compared with the validation data set, FN proposed had a coefficient of determination $\left(R^{2}\right)$ value of 0.86 , root mean square error (RMSE) of $12.45 \mathrm{~g} / \mathrm{d}$, and did not result in significant mean or linear bias $(P$ $>0.10)$.

\section{Urinary Nitrogen}

The total variation associated with predicting UN was higher than that for FN. None of the alternative equations was markedly better than the UN equation used in the CNCPS, which had the highest CCC (0.84) and lowest MSPE (1,983). Every equation except UN 5 overpredicted UN. Currently, the CNCPS calculates UN by difference (Table 4) making the accuracy of the FN prediction an important component in calculating UN. Given the performance of the UN equation in the current CNCPS (UN CNCPS) compared with alternatives, the FN prediction in the UN CNCPS (FN CNCPS) was replaced with FN proposed and this new UN equation (UN proposed) was also tested (Figure 2). The equation is described as follows: UN proposed = $\mathrm{NI}-\{\mathrm{FN}+[(\mathrm{SPA}+\mathrm{MPpreg}+\mathrm{MPg}) / 6.25]+[(\mathrm{milk}$ $\times$ milk $\mathrm{CP} \times 10) / 6.38]\}$, where $\mathrm{SPA}=$ requirement of net protein for scurf losses, $\mathrm{MP}_{\mathrm{Preg}}=\mathrm{MP}$ requirement for pregnancy, and $\mathrm{MP}_{\mathrm{g}}=\mathrm{MP}$ requirement for gain. Scurf losses are calculated as follows: $\mathrm{SPA}=0.20 \times$ shrunk BW $\mathrm{BW}^{0.6} / 0.67$. The results (Table 6 ) show that UN proposed had less total variation $(\mathrm{RMSE}=12.73 \mathrm{~g} / \mathrm{d})$ and a higher $\mathrm{R}_{\mathrm{MP}}^{2}$ than the UN CNCPS (0.86). Accuracy was also improved with an MSPE of 970 rather than 1,983 , and a slope of 0.93 rather than 0.86 . The percentage of error due to model bias was $25 \%$ lower than the UN CNCPS and the CCC increased from 0.84 to 0.90 , indicating a more accurate and precise prediction of UN. Compared with the validation data set, UN proposed had an RMSE of $15.42 \mathrm{~g} / \mathrm{d}$, explained a large proportion of the variation $\left(\mathrm{R}^{2}=0.91\right)$ and did not result in significant mean bias $(P>0.01)$. A significant linear bias $(P<0.001)$ of $19 \%$ was detected, which equates to approximately $33 \mathrm{~g}$ of $\mathrm{N}$ for the mean treatment in the data set. This is consistent with the mean unaccounted $\mathrm{N}$ from the validation data set of $6 \%$ or 35 g.

\section{Manure and Total Nitrogen}

The CNCPS calculates MN as the sum of FN and UN. The proposed changes to FN and UN translate into a more accurate prediction of MN (Table 6). Mean unaccounted study $\mathrm{N}$ was $1.5 \%$ for the whole data set, which is similar to the $3 \%$ overprediction of MN by MN proposed $\left(\beta_{1} \mathrm{MN}\right.$ proposed $\left.=0.97\right)$. The MSPE was decreased from 998 to 623 and the proportion of error due to model biases was decreased by $25 \%$. The increase in accuracy came at no cost to precision, with both $\mathrm{R}_{\mathrm{BLUP}}^{2}$ and $\mathrm{R}_{\mathrm{MP}}^{2}$ remaining unchanged at 0.99 and 0.96 , respectively. The CCC increased from 0.96 to 0.97 , indicating a small simultaneous change in the accuracy and precision of the model. The ability of the model to account for total $\mathrm{N}$ was also tested for the current and proposed equations. Both had a slope of 1.00 and an $\mathrm{R}_{\mathrm{BLUP}}^{2}$ and $\mathrm{R}_{\mathrm{MP}}^{2}$ of 1.00 , respectively. However, the intercept of the total N (TN) CNCPS was $-11.11 \mathrm{~g} / \mathrm{d}$, whereas TN proposed was $1.38 \mathrm{~g} / \mathrm{d}$. The intercept in TN should represent scurf losses, meaning a negative value is unrealistic and suggests a small bias in $\mathrm{N}$ utilization within the model.

\section{DISCUSSION}

The alternative equations evaluated in the current analysis (FN 1-4 and UN 1-5) were themselves all developed from large data sets and derived using mixed model statistical procedures to account for random error among studies. Simple linear regressions can 
Table 5. Model adequacy statistics for the prediction of fecal N (FN; g/d) and urinary N (UN; g/d) from the Cornell Net Carbohydrate and Protein System (CNCPS) and alternative equations

\begin{tabular}{|c|c|c|c|c|c|c|c|c|c|c|c|c|}
\hline \multirow[b]{2}{*}{ Equation } & \multirow[b]{2}{*}{ Slope $^{1}$} & \multirow[b]{2}{*}{$\mathrm{R}_{\text {BLUP }}^{2}$} & \multirow[b]{2}{*}{$\mathrm{R}_{\mathrm{MP}}^{2}{ }^{3}$} & \multirow[b]{2}{*}{$\mathrm{RMSE}^{4}$} & \multicolumn{3}{|c|}{ Variance component $^{5}(\%)$} & \multirow[b]{2}{*}{$\mathrm{CCC}^{6}$} & \multirow[b]{2}{*}{$\mathrm{MSPE}^{7}$} & \multicolumn{3}{|c|}{ MSPE partitioned $^{8}(\%)$} \\
\hline & & & & & Study & Slope & Residual & & & $U^{\mathrm{M}}$ & $U^{S}$ & $U^{\mathrm{R}}$ \\
\hline FN CNCPS & 1.00 & 0.98 & 0.69 & 10.48 & 85.19 & 0.04 & 14.77 & 0.80 & 884 & 1 & 1 & 98 \\
\hline FN 1 & 1.20 & 0.97 & 0.73 & 10.38 & 85.32 & 0.01 & 14.67 & 0.59 & 2,307 & 64 & 3 & 33 \\
\hline FN 2 & 1.17 & 0.98 & 0.72 & 9.67 & 87.34 & 0.02 & 12.64 & 0.63 & 2,052 & 60 & 2 & 38 \\
\hline FN proposed & 1.00 & 0.97 & 0.73 & 10.38 & 85.33 & 0.01 & 14.66 & 0.83 & 781 & 3 & 0 & 97 \\
\hline FN 4 & 1.00 & 0.98 & 0.72 & 9.67 & 87.34 & 0.01 & 12.65 & 0.83 & 810 & 4 & 0 & 96 \\
\hline FN 5 & 1.00 & 0.98 & 0.73 & 9.95 & 86.12 & 0.01 & 13.87 & 0.84 & 787 & 5 & 0 & 95 \\
\hline UN CNCPS & 0.86 & 0.96 & 0.83 & 14.84 & 69.28 & 0.00 & 30.72 & 0.84 & 1,983 & 28 & 36 & 35 \\
\hline UN 1 & 0.76 & 0.97 & 0.79 & 13.85 & 81.03 & 0.00 & 18.97 & 0.67 & 5,579 & 55 & 29 & 15 \\
\hline UN 2 & 0.76 & 0.93 & 0.36 & 20.90 & 89.01 & 0.01 & 10.99 & 0.45 & 9,087 & 34 & 37 & 29 \\
\hline UN 3 & 0.83 & 0.97 & 0.89 & 12.68 & 68.86 & 0.00 & 31.14 & 0.81 & 2,365 & 61 & 21 & 19 \\
\hline UN 4 & 0.84 & 0.97 & 0.88 & 12.65 & 63.44 & 0.00 & 36.56 & 0.83 & 1,985 & 62 & 14 & 24 \\
\hline UN 5 & 1.09 & 0.97 & 0.75 & 14.18 & 87.39 & 0.14 & 12.46 & 0.59 & 2,035 & 6 & 43 & 52 \\
\hline
\end{tabular}

${ }^{1}$ Slope of linear regression (intercepts were forced through the origin).

${ }^{2} \mathrm{R}_{\mathrm{BLUP}}^{2}=$ squared sample correlation coefficient based on BLUP.

${ }^{3} \mathrm{R}_{\mathrm{MP}}^{2}=$ squared sample correlation coefficient based on model-predicted estimates.

${ }^{4}$ Root mean square error.

${ }^{5}$ Percentage of variance related to the effect of study, differences in slope between study (study $\times$ prediction), and random variation.

${ }^{6}$ Concordance correlation coefficient.

${ }^{7}$ Mean square prediction error

$\stackrel{\varrho}{\mathrm{O}} \quad{ }^{8} U^{\mathrm{M}}=$ percentage of error due to mean bias, $U^{\mathcal{S}}=$ percentage of error due to systematic bias, $U^{\mathrm{R}}=$ percentage of error due to random variation. $U^{\mathrm{M}}+U^{\mathcal{S}}+U^{\mathrm{R}}=100$. 


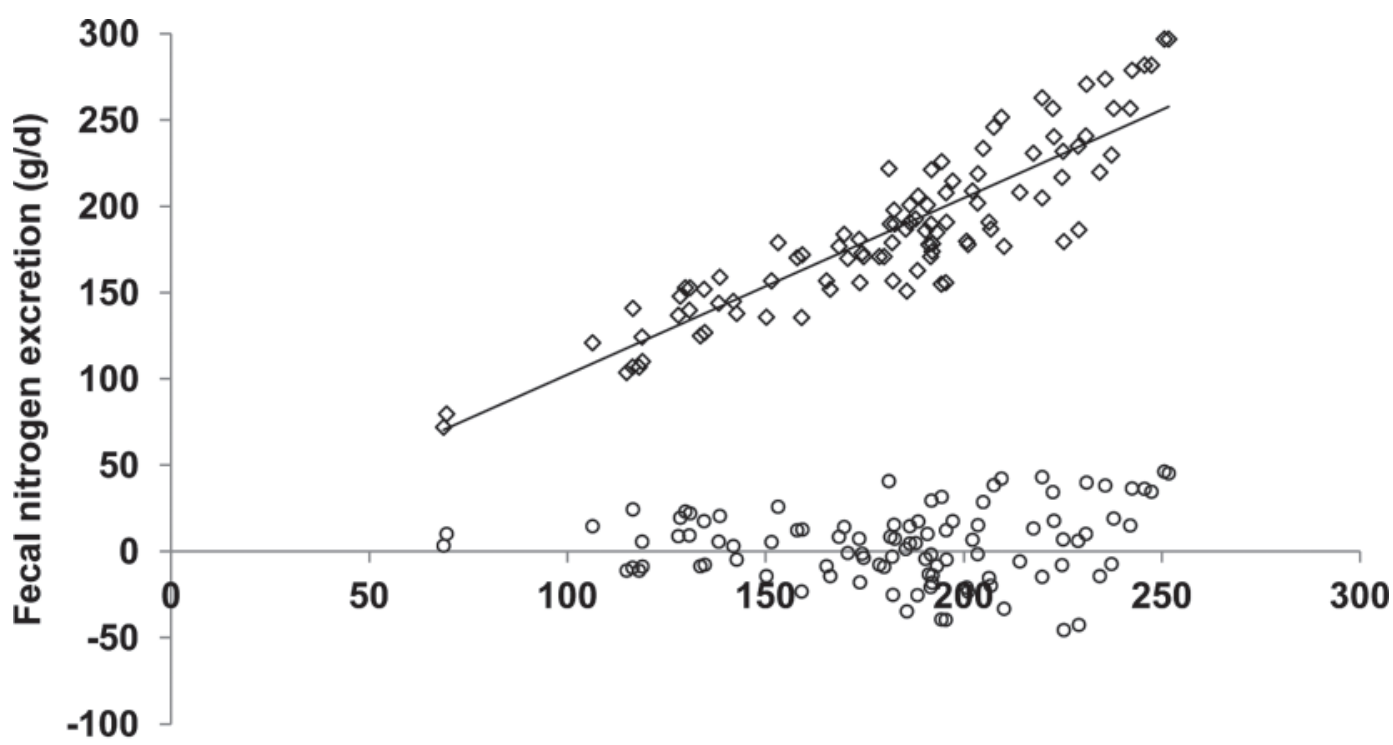

Fecal nitrogen excretion $(\mathbf{g} / \mathbf{d})$

Figure 1. Observed versus predicted fecal nitrogen $(\mathrm{FN})$ excretion $(\diamond)$ and residuals $(\bigcirc)$ of the mixed model analysis for FN proposed [FN $=(\{[\mathrm{NI}(\mathrm{g} / \mathrm{kg}$ of $\mathrm{OM}) \times(1-0.842)]+4.3\} \times \mathrm{OMI}) \times 1.20]$, where NI is $\mathrm{N}$ intake and OMI is OM intake. The regression has slope $=1$, $\mathrm{R}_{\mathrm{BLUP}}^{2}=0.97, \mathrm{R}_{\mathrm{MP}}^{2}=0.73$, and root mean square error $(\mathrm{RMSE})=10.38 \mathrm{~g} / \mathrm{d}$. MP $=$ model predictions.

lead to a misinterpretation of biological relationships (St-Pierre, 2001). Therefore, studies that did not use a mixed model analyses or that did not account for study appropriately when deriving prediction equations were not considered. The data set used to derive and test the equations in this study encompassed a wide range of milk production, NI, DMI and ration compositions to ensure the assessment had relevance to a broad range of production systems. Considerable care was taken to ensure that the treatments included in the

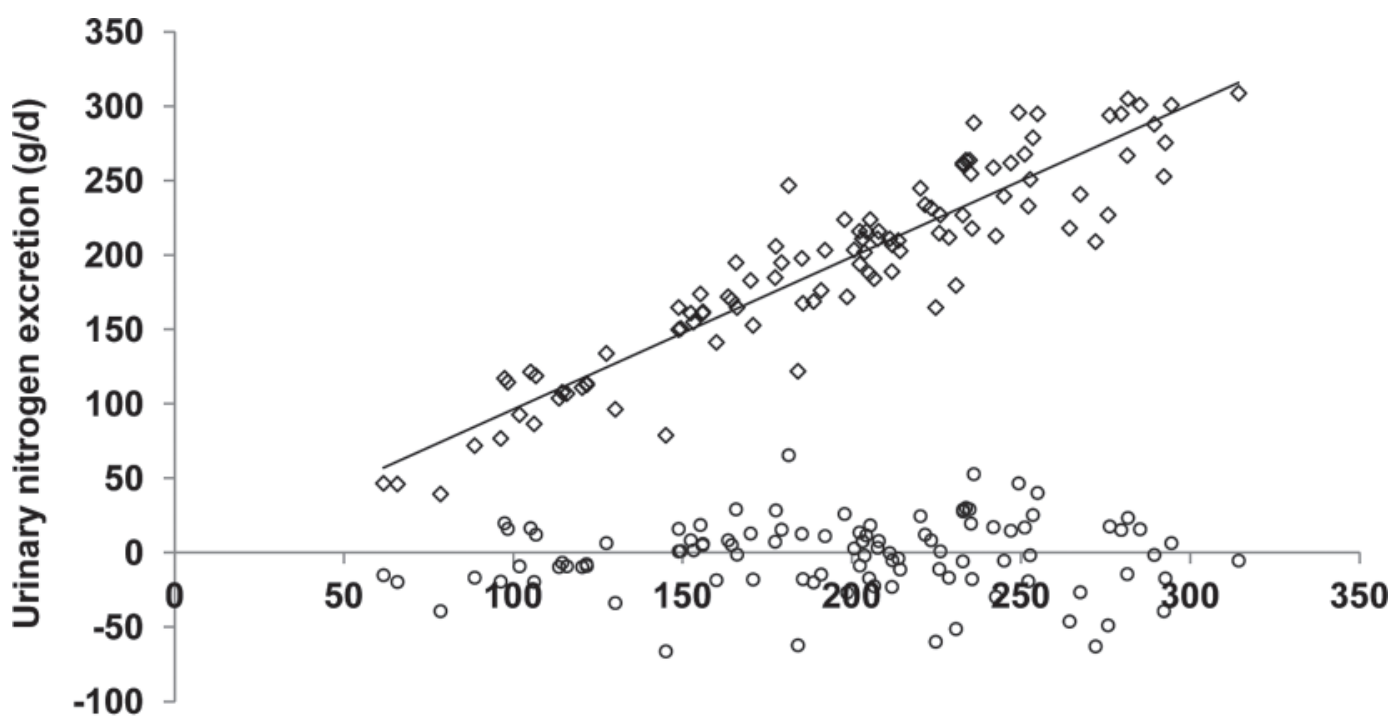

Urinary nitrogen excretion $(g / d)$

Figure 2. Observed versus predicted urinary nitrogen $(\mathrm{UN})$ excretion $(\diamond)$ and residuals $(\bigcirc)$ of the mixed model analysis for UN proposed $=$ $\mathrm{NI}-\{\mathrm{FN}+[(\mathrm{SPA}+\mathrm{MPpreg}+\mathrm{MPg}) / 6.25]+[($ milk $\times$ milk CP $\times 10) / 6.38]\}$, where NI $=\mathrm{N}$ intake, SPA $=$ requirement of net protein for scurf losses, $\mathrm{MP}_{\text {Preg }}=\mathrm{MP}$ requirement for pregnancy, and $\mathrm{MP}_{\mathrm{g}}=\mathrm{MP}$ requirement for gain. The regression has a slope $=0.93, \mathrm{R}_{\mathrm{BLUP}}^{2}=0.97$, $\mathrm{R}_{\mathrm{MP}}^{2}=0.86$, and root mean square error $(\mathrm{RMSE})=12.73 \mathrm{~g} / \mathrm{d} . \mathrm{MP}=$ model predictions. 
data set used sound methodology and accounted for greater than $90 \%$ of the NI in the milk, feces, and urine. Nitrogen balance studies often overestimate $\mathrm{N}$ retention due to losses incurred during collection and analysis (Bockmann et al., 1996; Spanghero and Kowalski, 1997; Castillo et al., 2000; Reynolds and Kristensen, 2008). Providing the animals used in balance studies are fully grown, in mid to late lactation and not in the last trimester of pregnancy, intake $\mathrm{N}$ should be approximate to the amount of $\mathrm{N}$ lost from the body (Hegsted, 1976). Despite this, even the most carefully conducted $\mathrm{N}$ balance studies are unable to account for all of the intake $\mathrm{N}$, resulting in an overestimation of retained $\mathrm{N}$ (Spanghero and Kowalski, 1997). Edits were made to the current data set to account for scurf $\mathrm{N}$ losses, FN losses when feces were dried before analysis, and differences in milk $\mathrm{N}$ based on the analytical method used. The editing process decreased unaccounted $\mathrm{N}$ from 5.1 to $1.5 \%$ of NI, which is lower than comparable data sets from Spanghero and Kowalski (1997) and Bockmann et al. (1996) who reported unaccounted $\mathrm{N}$ of 4.4 and $6.0 \%$ of NI, respectively. It must be noted that error in the chemical analysis of the ration fed, DMI measurements, milk yield, and the analysis of milk protein might also contribute to error in $\mathrm{N}$ balance estimates, which is not often mentioned. Although this might be considered random error, within study, this type of error can lead to systematic bias if analytical instruments or other equipment are incorrectly calibrated or are not uniform in their range of composition.

The current CNCPS framework relies on a combination of measured inputs and empirical predictions to account for $\mathrm{N}$ utilization within the animal. Urinary $\mathrm{N}$ is calculated as the difference between NI, the sum of $\mathrm{N}$ accretion, milk N, N retained by the conceptus, scurf N, and FN (Table 4). This means a misrepresentation of any of these factors will cause a subsequent error in UN. Having the model structured in this way essentially pools the input error from other parameters into UN, which may be a reason for the large portion of the MSPE in UN being accounted for by model biases (Table 5) and the significant linear bias observed when comparing UN proposed to the validation data set. It also makes the accuracy of dietary and animal inputs critical in predicting both $\mathrm{MN}$ and the partitioning of FN and UN. From a modeling standpoint, structuring the model in this manner enables $\mathrm{N}$ to first be accounted for from measured parameters (DMI and milk), and then from parameters that are routinely predicted (i.e., maintenance, pregnancy, and growth). This leaves a smaller pool of $\mathrm{N}$ that needs to be empirically accounted for, and translates the accuracy of other, more robust measurements, to the prediction of more variable parameters. The random effect of study in the 
mixed model analysis accounted for a high proportion of variation in both $\mathrm{FN}$ and UN predictions and resulted in high $\mathrm{R}_{\text {BLUP }}^{2}$ values (Tables 5 and 6 , respectively). In practice, $\mathrm{R}_{\text {BLUP }}^{2}$ can be misleading, as random farm-to-farm variation cannot be accounted for, given that no measured values exist to compare model predictions to. Consequently, $\mathrm{R}_{\mathrm{MP}}^{2}$ values were also presented, which use an average study effect across the whole data set and give a better indication of the amount of variation the model may explain in the practical situation.

Fecal $\mathrm{N}$ is calculated in the CNCPS as the residual from the digestion of $\mathrm{B} 3$ and $\mathrm{C}$ protein fractions, bacterial losses, and losses from protein bound to the indigestible DM (IDM; Table 4). Compared with observed values, the current $\mathrm{FN}$ equation in the CNCPS predicted FN accurately (slope $=1.00, \mathrm{MSPE}=884$ ), which is in contrast to the suggestions of Fox et al. (2004) that, due to some of the metabolic N losses and IDM also being accounted for in the bacterial $\mathrm{N}$ fraction, the equation would overpredict FN. Huhtanen et al. (2008) showed that bivariate equations including both DMI and NI as independent variables are able to predict FN more precisely than univariate models that are simple functions of DMI or NI. Biologically, metabolic, and endogenous $\mathrm{N}$ are related to DMI, whereas undigested feed $\mathrm{N}$ is related to NI, meaning that the bivariate model is able to account for the origin of each of the FN sources more correctly (Huhtanen et al., 2008; Marini et al., 2008). Marini et al. (2008) also found that the fermentation rate of dietary NDF has an important effect on determining endogenous $\mathrm{N}$ losses. Increasing levels of NDF appeared to reduce apparently digested $\mathrm{N}$; however, rapidly fermenting carbohydrates increased apparent total tract $\mathrm{N}$ digestion. Carbohydrates that ferment more slowly can reach the hindgut and provide an energy source for microbes that trap N, and are subsequently excreted in the feces (Dewhurst and Thomas, 1992; Tamminga, 1992; Van Soest, 1994). Both equations FN 1 and 2 calculated FN based on functions of NI and DMI (FN 2) or OM intake (OMI; FN 1) and were able to account for FN more precisely than the FN CNCPS. However, both equations considerably underpredicted total FN. Interestingly, the systematic bias associated with equations FN 1 and 2 was low, indicating that the biological relationship between the 2 equations was similar. The large mean bias and subsequent underprediction of FN could be explained by simple differences in the level of unaccounted $\mathrm{N}$ from the $\mathrm{N}$ balance data used to derive the equations. Adjusting FN 1 and 2 based on the level of under prediction (FN proposed and FN 4) resulted in more accurate and precise predictions of $\mathrm{FN}$ than the $\mathrm{FN}$ equation in the CNCPS. The relationship of FN excretion from the current data set (FN 5) was comparable to that developed by Huhtanen et al. (2008). However, both equations resulted in a negative intercept, which is biologically impossible. Huhtanen et al. (2008) attempted to solve this problem by using a quadratic model but found the linear model to be more precise. Another alternative was to predict FN per unit of DMI or OMI as presented by Marini et al. (2008), which, when calibrated to the current data set (FN proposed), resulted in the most accurate and precise prediction of $\mathrm{FN}$ tested $\left(\mathrm{R}_{\mathrm{MP}}^{2}=0.73, \mathrm{MSPE}=781\right)$ and also compared favorably to the validation data set.

The majority of excess $\mathrm{N}$ not utilized for growth or production is excreted in the urine, regardless of whether it is absorbed as AA or simply ammonia (Broderick, 2007). True endogenous $\mathrm{N}$ or maintenance losses are the only real constant source of UN and account for approximately $0.35 \mathrm{~g}$ of $\mathrm{N} / \mathrm{kg}$ of metabolic weight per day (Dewhurst and Thomas, 1992). Other more variable sources include rumen-degradable $\mathrm{N}$ not incorporated into microbial protein, metabolites of microbial nucleic acids, and products of the incomplete utilization of absorbed AA (Tamminga, 1992). Many of the equations used to predict UN in the literature use functions of MUN because it has a direct relationship with UN and is relatively easy to measure (Jonker et al., 1998; Kauffman and St-Pierre, 2001; Nennich et al., 2006; Burgos et al., 2007). However, using MUN to predict UN in the CNCPS would mean an additional input, without which, UN could not be predicted and diets could not be preemptively formulated to lower UN on a group-specific basis. This may limit the usefulness of the CNCPS as a nutrient management tool and adds an additional source of variation from the analysis of MUN (Arunvipas et al., 2004, Peterson et al., 2004). Predictions based on dietary parameters, milk production (UN 1-5), or both, were less accurate than the UN CNCPS which, despite overpredicting UN by $14 \%$, was the best predictor of UN tested $(\mathrm{CCC}=0.84)$. The overprediction in UN CNCPS could be explained by an error in the UN calculation within the model where a portion of productive $\mathrm{N}$ was not subtracted from the UN equation, resulting in a pool of $\mathrm{N}$ being accounted for twice (TN CNCPS; Table 6). The data set used to derive UN 1 to 4 estimated UN based on the difference between NI, milk N, and FN (Huhtanen et al., 2008). The analysis of FN 2 indicated that unaccounted FN in the data set of Huhtanen et al. (2008) was $17 \%$ higher than in the current data set, which explains the overprediction and large mean bias of UN from UN 1 to 4 . In contrast, the data set used to derive UN 5 was based on UN measurements from $\mathrm{N}$ balance studies (Nennich 
et al., 2006) so the $9 \%$ overprediction was probably due to differences in the level of unaccounted N. Given the difficulties in establishing a robust data set from which to derive UN predictions, the UN equation in CNCPS was re-derived (UN proposed) using $\mathrm{FN}$ proposed to predict FN outputs. The resulting equation (UN proposed) still overpredicted UN by $7 \%$, but this corresponded more closely to the $1.5 \%$ total unaccounted $\mathrm{N}$ in the current data set, and the accuracy and precision of UN predictions was considerably improved (Table 6 ). The improvement in the FN and UN predictions improved the $6 \%$ overprediction of the MN estimates in the CNCPS and aligned MN more closely to the current data set (MN proposed). Implementing these changes would result in a more accurate and precise prediction of UN, FN, and MN and improve the usefulness of the CNCPS as a nutrient management tool.

\section{CONCLUSIONS}

To comply with future environmental standards, robust methods that quantify $\mathrm{N}$ outputs from dairy farms are required. The results of this study show the prediction of FN, UN, and TN in the CNCPS can be improved through the adoption of a new FN equation $[$ FN proposed $=(\{[\mathrm{NI}(\mathrm{g} / \mathrm{kg}$ of $\mathrm{OM}) \times(1-0.842)]+$ $4.3\} \times \mathrm{OMI}) \times 1.20]$, and a reconstruction of the $\mathrm{UN}$ equation to account for bias in $\mathrm{N}$ utilization within the model: UN proposed $=\mathrm{NI}-\{\mathrm{FN}+[(\mathrm{SPA}+\mathrm{MP}-$ preg $+\mathrm{MPg}) / 6.25]+[($ milk $\times$ milk $\mathrm{CP} \times 10) / 6.38]\}$. Incorporation of the equations $\mathrm{FN}$ proposed and UN proposed would improve the prediction of $\mathrm{FN}$ and UN in the CNCPS (version 6.1).

\section{REFERENCES}

Arunvipas, P., J. A. VanLeeuwen, I. R. Dohoo, and G. P. Keefe. 2004. Bulk tank milk urea nitrogen: Seasonal patterns and relationship to individual cow milk urea nitrogen values. Can. J. Vet. Res. 68:169-174.

Beckman, J. L., and W. P. Weiss. 2005. Nutrient digestibility of diets with different fiber to starch ratios when fed to lactating dairy cows. J. Dairy Sci. 88:1015-1023.

Birkelo, C. P., M. J. Brouk, and D. J. Schingoethe. 2004. The energy content of wet corn distillers grains for lactating dairy cows. J. Dairy Sci. 87:1815-1819.

Bockmann, H. C., W. Junge, and E. Kalm. 1996. A method of measuring the nitrogen balances from dairy cows under loose housing conditions. Arch. Anim. Breed. 39:361-368.

Brito, A. F., G. F. Tremblay, A. Bertrand, Y. Castonguay, G. Bélanger, R. Michaud, H. Lapierre, C. Benchaar, H. V. Petit, D. R. Ouellet, and R. Berthiaume. 2008. Alfalfa cut at sundown and harvested as baleage improves milk yield of late-lactation dairy cows. J. Dairy Sci. 91:3968-3982.

Broderick, G. A. 2007. Reduced crude protein rations for high producing cows: Production and environmental effects. Pages $61-71$ in Proc. Cornell Nutrition Conference. Department of Animal Science, Cornell University, Syracuse, NY.
Burgos, S. A., J. G. Fadel, and E. J. DePeters. 2007. Prediction of ammonia emission from dairy cattle manure based on milk urea nitrogen: Relation of milk urea nitrogen to urine urea nitrogen excretion. J. Dairy Sci. 90:5499-5508.

Castillo, A. R., E. Kebreab, D. E. Beever, J. H. Barbi, J. D. Sutton, H. C. Kirby, and J. France. 2001. The effect of energy supplementation on nitrogen utilization in lactating dairy cows fed grass silage diets. J. Anim. Sci. 79:240-246.

Castillo, A. R., E. Kebreab, D. E. Beever, and J. France. 2000. A review of efficiency of nitrogen utilization in lactating dairy cows and its relationship with environmental pollution. J. Anim. Feed Sci. 9:1-32.

Cherney, D. J. R., J. H. Cherney, and L. E. Chase. 2003. Influence of dietary nonfiber carbohydrate concentration and supplementation of sucrose on lactation performance of cows fed fescue silage. J. Dairy Sci. 86:3983-3991.

Dewhurst, R. J., and C. Thomas. 1992. Modeling of nitrogen transactions in the dairy cow and their environmental consequences. Livest. Prod. Sci. 31:1-16.

Dinn, N. E., J. A. Shelford, and L. J. Fisher. 1998. Use of the Cornell Net Carbohydrate and Protein System and rumen-protected lysine and methionine to reduce nitrogen excretion from lactating dairy cows. J. Dairy Sci. 81:229-237.

Dou, Z., L. E. Lanyon, J. D. Ferguson, R. A. Kohn, R. C. Boston, and W. Chalupa. 1998. An integrated approach to managing nitrogen on dairy farms: Evaluating farm performance using dairy nitrogen planner. Agron. J. 90:573-581.

Drackley, J. K., and J. P. Elliott. 1993. Milk composition, ruminal characteristics, and nutrient utilization in dairy cows fed partially hydrogenated tallow. J. Dairy Sci. 76:183-196.

Elliott, J. P., J. K. Drackley, D. J. Schauff, and E. H. Jaster. 1993. Diets containing high oil corn and tallow for dairy cows during early lactation. J. Dairy Sci. 76:775-789.

Erdman, R. A., R. W. Hemken, and L. S. Bull. 1982. Dietary sodium bicarbonate and magnesium oxide for early postpartum lactating dairy cows: Effects of production, acid-based metabolism, and digestion. J. Dairy Sci. 65:712-731.

Flis, S. A., and M. A. Wattiaux. 2005. Effects of parity and supply of rumen-degraded and undegraded protein on production and nitrogen balance in Holsteins. J. Dairy Sci. 88:2096-2106.

Fox, D. G., L. O. Tedeschi, T. P. Tylutki, J. B. Russell, M. E. Van Amburgh, L. E. Chase, A. N. Pell, and T. R. Overton. 2004. The Cornell Net Carbohydrate and Protein System model for evaluating herd nutrition and nutrient excretion. Anim. Feed Sci. Technol. 112:29-78.

Grieve, D. G., W. G. Merrill, and C. E. Coppock. 1973. Sulfur supplementation of urea-containing silages and concentrates II: Ration digestibility, nitrogen, and sulfur balances. J. Dairy Sci. 56:224228.

Gruber, L., A. Steinwidder, B. Stefanon, B. Steiner, and R. Steinwender. 1999. Influence of grassland management in alpine regions and concentrate level on $\mathrm{N}$ excretion and milk yield of dairy cows. Livest. Prod. Sci. 61:155-170.

Haig, P. A., T. Mutsvangwa, R. Spratt, and B. W. McBride. 2002. Effects of dietary protein solubility on nitrogen losses from lactating dairy cows and comparison with predictions from the Cornell Net Carbohydrate and Protein System. J. Dairy Sci. 85:1208-1217.

Hegsted, D. M. 1976. Balance studies. J. Nutr. 106:307-311.

Holden, L. A., B. P. Glenn, R. A. Erdman, and W. E. Pots. 1994. Effects of alfalfa and orchardgrass on digestion by dairy cows. J. Dairy Sci. 77:2580-2594.

Hristov, A. N., K. L. Grandeen, J. K. Ropp, and M. A. McGuire. 2004. Effect of sodium laurate on ruminal fermentation and utilization of ruminal ammonia nitrogen for milk protein synthesis in dairy cows. J. Dairy Sci. 87:1820-1831.

Huhtanen, P., J. I. Nousiainen, M. Rinne, K. Kytölä, and H. Khalili. 2008. Utilization and partition of dietary nitrogen in dairy cows fed grass silage-based diets. J. Dairy Sci. 91:3589-3599.

Jacobson, D. R., B. Soewardi, J. W. Barnett, R. H. Hatton, and S. B. Carr. 1969. Sulfur, nitrogen, and amino acid balance, and digest- 
ibility of low-sulfur and sulfur-supplemented diets fed to lactating cows. J. Dairy Sci. 52:472-478.

Jonker, J. S., D. J. R. Cherney, D. G. Fox, L. E. Chase, and J. H. Cherney. 2002. Orchardgrass versus alfalfa for lactating dairy cattle: Production, digestibility and nitrogen balance. J. Appl. Anim. Res. 21:81-92.

Jonker, J. S., R. A. Kohn, and R. A. Erdman. 1998. Using milk urea nitrogen to predict nitrogen excretion and utilization efficiency in lactating dairy cows. J. Dairy Sci. 81:2681-2692.

Juko, C. D., R. M. Bredon, and B. Marshall. 1961. Nutrition of Zebu Cattle. 2. Techniques of digestibility trials with special reference to sampling, preservation and drying of faeces. J. Agric. Sci. 56:93-97.

Kauffman, A. J., and N. R. St-Pierre. 2001. The relationship of milk urea nitrogen to urine nitrogen excretion in Holstein and Jersey cows. J. Dairy Sci. 84:2284-2294

Knowlton, K. F., J. H. Herbein, M. A. Meister-Weisbarth, and W A. Wark. 2001. Nitrogen and phosphorus partitioning in lactating Holstein cows fed different sources of dietary protein and phosphorus. J. Dairy Sci. 84:1210-1217.

Marini, J. C., D. G. Fox, and M. R. Murphy. 2008. Nitrogen transactions along the gastrointestinal tract of cattle: A meta-analytical approach. J. Anim. Sci. 86:660-679.

Martineau, R., H. Lapierre, D. R. Ouellet, D. Pellerin, and R. Berthiaume. 2007. Effects of the method of conservation of timothy on nitrogen metabolism in lactating dairy cows. J. Dairy Sci. 90:2870-2882

Moorby, J. M., M. R. F. Lee, D. R. Davies, E. J. Kim, G. R. Nute, N. M. Ellis, and N. D. Scollan. 2009. Assessment of dietary ratios of red clover and grass silages on milk production and milk quality in dairy cows. J. Dairy Sci. 92:1148-1160.

Nennich, T. D., J. H. Harrison, L. M. VanWieringen, D. Meyer, A J. Heinrichs, W. P. Weiss, N. R. St-Pierre, R. L. Kincaid, D. L. Davidson, and E. Block. 2005. Prediction of manure and nutrient excretion from dairy cattle. J. Dairy Sci. 88:3721-3733.

Nennich, T. D., J. H. Harrison, L. M. VanWieringen, N. R. St-Pierre, R. L. Kincaid, M. A. Wattiaux, D. L. Davidson, and E. Block. 2006. Prediction and evaluation of urine and urinary nitrogen and mineral excretion from dairy cattle. J. Dairy Sci. 89:353-364.

Noftsger, S., and N. R. St-Pierre. 2003. Supplementation of methionine and selection of highly digestible rumen undegradable protein to improve nitrogen efficiency for milk production. J. Dairy Sci. 86:958-969.

NRC. 2001. Nutrient Requirements of Dairy Cattle. 7th rev. ed. National Academy Press, Washington, DC.

NRC. 2003. Air Emissions from Animal Feeding Operations: Current Knowledge, Future Needs. National Academy Press, Washington, $\mathrm{DC}$

OECD (Organisation for Economic Co-operation and Development). 2004. Agriculture, Trade, and the Environment: The Dairy Sector. Organisation for Economic Co-operation and Development, Paris, France.

Peterson, A. B., K. R. French, E. Russek-Cohen, and R. A. Kohn. 2004. Comparison of analytical methods and the influence of milk components on milk urea nitrogen recovery. J. Dairy Sci. $87: 1747-1750$

Petit, H. V., and G. F. Tremblay. 1995. Ruminal fermentation and digestion in lactating cows fed grass silage with protein and energy supplements. J. Dairy Sci. 78:342-352.

Raggio, G., D. Pacheco, R. Berthiaume, G. E. Lobley, D. Pellerin, G Allard, P. Dubreuil, and H. Lapierre. 2004. Effect of level of metabolizable protein on splanchnic flux of amino acids in lactating dairy cows. J. Dairy Sci. 87:3461-3472.

Reynolds, C. K., and N. B. Kristensen. 2008. Nitrogen recycling through the gut and the nitrogen economy of ruminants: An asynchronous symbiosis. J. Anim. Sci. 86 (E. Suppl.):E293-E305.
Ruiz, R., G. L. Albrecht, L. O. Tedeschi, G. Jarvis, J. B. Russell, and D. G. Fox. 2001. Effect of monensin on the performance and nitrogen utilization of lactating dairy cows consuming fresh forage. J. Dairy Sci. 84:1717-1727.

Ruiz, R., L. O. Tedeschi, J. C. Marini, D. G. Fox, A. N. Pell, G. Jarvis, and J. B. Russell. 2002. The effect of a ruminal nitrogen (N) deficiency in dairy cows: Evaluation of the Cornell Net Carbohydrate and Protein Systems ruminal N deficiency adjustment. J. Dairy Sci. 85:2986-2999.

SAS Institute. 2007. JMP. SAS Institute Inc., Cary, NC.

Schauff, D. J., J. P. Elliott, J. H. Clark, and J. K. Drackley. 1992 Effects of feeding lactating dairy cows diets containing whole soybeans and tallow. J. Dairy Sci. 75:1923-1935.

Spanghero, M., and Z. M. Kowalski. 1997. Critical analysis of N balance experiments with lactating cows. Livest. Prod. Sci. 52:113122.

St-Pierre, N. R. 2001. Invited review: Integrating quantitative findings from multiple studies using mixed model methodology. J. Dairy Sci. 84:741-755.

Tamminga, S. 1992. Nutrition management of dairy cows as a contribution to pollution control. J. Dairy Sci. 75:345-357.

Tedeschi, L. O. 2006. Assessment of the adequacy of mathematical models. Agric. Syst. 89:225-247.

Tylutki, T. P., D. G. Fox, V. M. Durbal, L. O. Tedeschi, J. B. Russell, M. E. Van Amburgh, T. R. Overton, L. E. Chase, and A. N. Pell 2008. Cornell Net Carbohydrate and Protein System: A model for precision feeding of dairy cattle. Anim. Feed Sci. Technol. 143:174-202.

van Dorland, H. A., H. R. Wettstein, H. Leuenberger, and M. Kreuzer. 2007. Effect of supplementation of fresh and ensiled clovers to ryegrass on nitrogen loss and methane emission of dairy cows. Livest. Sci. 111:57-69.

Van Soest, P. J. 1994. Nutritional Ecology of the Ruminant. 2nd ed. Comstock Publications, Ithaca, NY.

Vanhatalo, A., K. Kuoppala, S. Ahvenjärvi, and M. Rinne. 2009. Effects of feeding grass or red clover silage cut at two maturity stages in dairy cows. 1. Nitrogen metabolism and supply of amino acids. J. Dairy Sci. 92:5620-5633.

Wattiaux, M. A., and K. L. Karg. 2004. Protein level for alfalfa and corn silage-based diets: II. Nitrogen balance and manure characteristics. J. Dairy Sci. 87:3492-3502.

Weiss, W. P., L. B. Willett, N. R. St-Pierre, D. C. Borger, T. R. McKelvey, and D. J. Wyatt. 2009. Varying forage type, metabolizable protein concentration, and carbohydrate source affects manure excretion, manure ammonia, and nitrogen metabolism of dairy cows. J. Dairy Sci. 92:5607-5619.

Weiss, W. P., and D. J. Wyatt. 2006. Effect of corn silage hybrid and metabolizable protein supply on nitrogen metabolism of lactating dairy cows. J. Dairy Sci. 89:1644-1653.

Wilkerson, V. A., B. P. Glenn, and K. R. McLeod. 1997. Energy and nitrogen balance in lactating cows fed diets containing dry or high moisture corn in either rolled or ground form. J. Dairy Sci. 80:2487-2496

Wohlt, J. E., S. L. Chmiel, P. K. Zajac, L. Backer, D. B. Blethen, and J. L. Evans. 1991. Dry matter intake, milk yield and composition, and nitrogen use in Holstein cows fed soybean, fish, or corn gluten meals. J. Dairy Sci. 74:1609-1622.

Wright, C. F., M. A. G. von Keyserlingk, M. L. Swift, L. J. Fisher, J. A. Shelford, and N. E. Dinn. 2005. Heat- and lignosulfonatetreated canola meal as a source of ruminal undegradable protein for lactating dairy cows. J. Dairy Sci. 88:238-243. 